Research Article

\title{
The implementation of mini-research project to train undergraduate students' scientific writing and communication skills
}

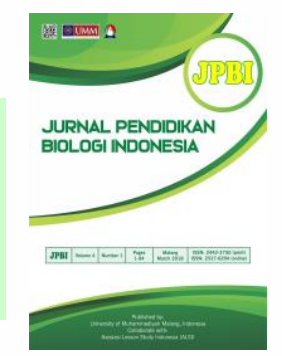

Agus Haryono a,1, Chaidir Adam a,2,

a Department of Biology Education, Faculty of Teacher Training and Education, University of Palangka Raya, JI. Damang Salilah I

Palangka Raya, Central Kalimantan 73111, Indonesia

1agus.haryono@fkip.upr.ac.id; 2chaidir.adam03@gmail.com*

* Corresponding author

\begin{tabular}{|c|c|}
\hline ARTICLE INFO & ABSTRACT \\
\hline $\begin{array}{l}\text { Article history } \\
\text { Received: } 28 \text { February } 2021 \\
\text { Revised: } 31 \text { May } 2021 \\
\text { Accepted: } 3 \text { June } 2021 \\
\text { Published: } 31 \text { July } 2021 \\
\\
\text { Keywords } \\
\text { Mini-Research Project } \\
\text { Animal Ecology Field Practice } \\
\text { Scientific Writing Skills } \\
\text { Communication Skills }\end{array}$ & $\begin{array}{l}\text { Scientific writing and communication skills of undergraduate students in the Biology } \\
\text { Education Program of University of Palangka Raya need to be improved. The purpose } \\
\text { of this research was to implement mini-research in animal ecology field practice to train } \\
\text { undergraduate students' scientific writing and communication skills. This descriptive } \\
\text { quantitative research used action-research method with two cycles in which each cycle } \\
\text { consisted of four stages i.e (1) plan; (2) take action; (3) collect and analyze evidences, } \\
\text { and (4) reflect. The data gained were analyzed descriptively and quantitatively. The } \\
\text { results showed that the gain score of students' scientific writing skills based on mini- } \\
\text { research assessment was } 0.6 \text { (moderate category). Moreover, students' communication } \\
\text { skills showed an improvement from cycle } 1 \text { to cycle } 2 \text { which was assessed during the } \\
\text { presentation session. All the findings in this study indicate that the implementation of } \\
\text { the mini-research project in the field practice of the animal ecology course helps } \\
\text { students to develop scientific writing and communication skills. } \\
\text { This is an open access article under the CC-BY-SA license } \\
\text { Copyright } \odot 2021 \text { Haryono \& Adam } \\
\text { aA }\end{array}$ \\
\hline $\begin{array}{r}\text { How to cite: Haryono, A } \\
\text { scientific writi } \\
\text { doi.org/10.22 }\end{array}$ & $\begin{array}{l}\text {. (2021). The implementation of mini-research project to train undergraduate students' } \\
\text { munication skills. JPBI (Jurnal Pendidikan Biologi Indonesia), 7(2), 159-170. doi: https:// } \\
15838\end{array}$ \\
\hline
\end{tabular}

\section{INTRODUCTION}

Scientific writing is key to the success of students in any discipline of science, especially for biology students (Javed et al., 2013; Moore, 1994; Simmons et al., 2014; Tonissen et al., 2014). Students are required to have competence in scientific writing to complete their studies by producing research reports in the form of a thesis with good scientific writing standards. Good scientific writing is a skill that is acquired personally through years of practice and the crucial challenge as an instructor is teaching our students how to write critically, logically, and concisely, while recognizing the value of compliance with well-established scientific standards (Simmons et al., 2014). Educating students in scientific writing in a field of science is the same as teaching them how to think critically in solving problems in that field (Barroga \& Mitoma, 2019; Nilson, 2003; Stephenson \& Sadler-McKnight, 2016; Tahira \& Haider, 2019). Writing also helps students improve their understanding of the material they are studying (Bangert-Drowns et al., 2004; Graham et al., 2011). As an effort to improve 
scientific writing skills, a student needs to improve their thinking skills. It is important for students to improve their thinking skills to a higher level to have an ability to write using logical arguments that are proven by evidence and the related literature to support their arguments.

The scientific writing skills of undergraduate students in the Biology Education Program, University of Palangka Raya still need improvement. The students' knowledge about how to report the results of field practice does not comply with scientific writing standards in most scientific journals for publication. Based on the preliminary observation known that the scientific writing skills of undergraduate students in the Biology Education Program, University of Palangka Raya, that still need to improve are data presentation, research methods, citation and reference, and plagiarism. It describes that the students have poor scientific writing skills, and may not understand the concepts being studied.

Good scientific writing skills are obtained through exercises facilitated by the teacher in a student-centered learning model, such as PjBL (Project Based Learning). PJBL has a significant effect on students' scientific writing skills, and through a collaborative environment in PjBL learning students can be helped to train and develop not only scientific writing skills, but also communication skills (Aghayani \& Hajmohammadi, 2019; Awang \& Daud, 2015; Hasani et al., 2017; Kovalyova et al., 2016; Mandow et al., 2014; Permana et al., 2021; Permana \& Setyawan, 2020; Rachmawati \& Asmara, 2018; Sagala et al., 2019). This research uses a modified form of learning from PjBL called mini-research project. The mini-research project is designed to be a form of simple research project-based learning in which students contribute dominantly, starting from research design, research implementation, and reporting research results in a scientific presentation.

Mini-research is a research-based field practice that can be implemented to improve scientific writing skills. Mini-research is not limited to practicing writing skills but also trains students to communicate their writing in a scientific presentation. According to Pechenik (2013) communicating appropriately is an essential part of all sciences because it provides a way to examine, evaluate, and share thinking with the scientific community. This research is aimed to implement mini-research in animal ecology field practice to train undergraduate students' scientific writing and communication skills.

\section{METHOD}

This research is descriptive quantitative research using the action-research method with 2 cycles (Figure 1). Each cycle consists of 4 stages (1) plan; (2) take action; (3) collect and analyze evidence; and (4) reflect (Somekh, 2006; Tripp, 2005).

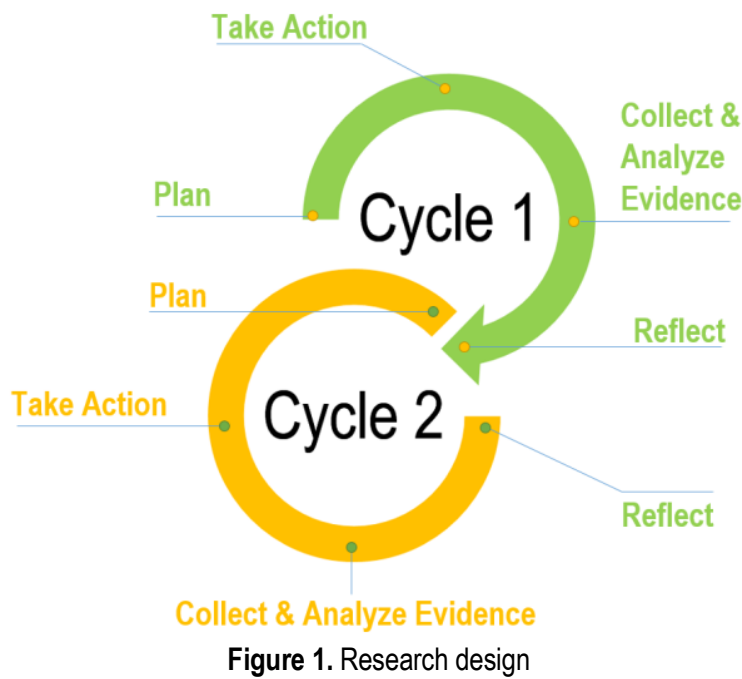

In the plan phase, all materials needed for the implementation of mini-research is well prepared, including (1) Mini-research technical guide, this technical guide contains the technical implementation procedures for mini-research in the animal ecology field practice; (2) Animal ecology field practice guide were created for two mini-research topics related to animal ecology studies. These guides contain detailed procedures for students to conduct a mini-research independently. The topics are earthworm diversity, and insect diversity; (3) Paper template as a predetermined template for students' mini-research reports. The template is created like a 
template for scientific articles for publication as the format for mini-research reports. This aims to provide experience to students in how to report a research result in a scientific paper (Figure 2).

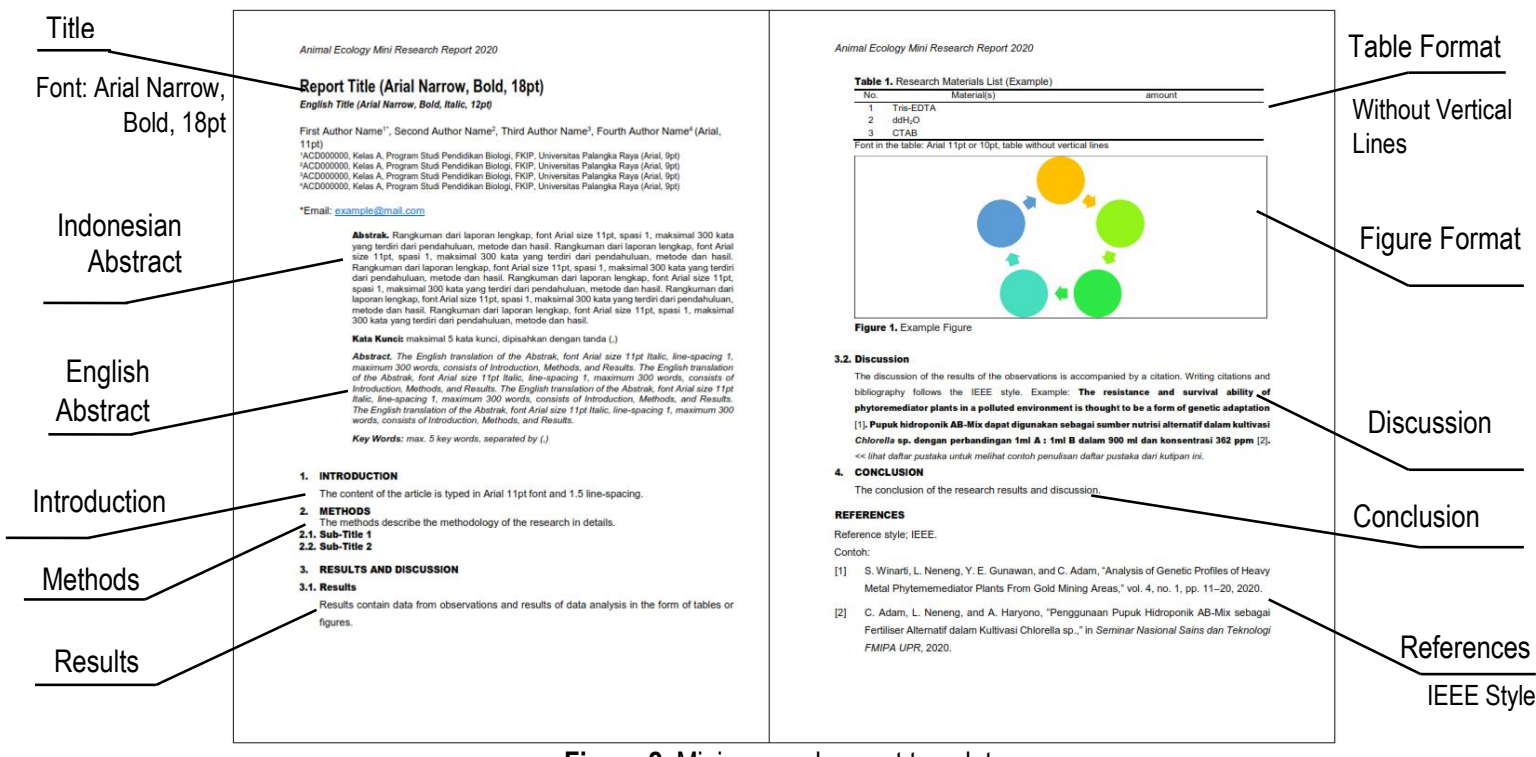

Figure 2. Mini-research report template

In the take action phase, the implementation phase of mini-research in animal ecology field practice. The details of the implementation procedure presented in Figure 3. Mini-Research implementation in animal ecology field practice which was carried out for six weeks. Students are allowed to work on a mini-research project for one week before presenting the results at the meeting in the second week. After the second presentation of topic 2 results, students are given the opportunity to complete a mini-research report for two weeks until the report meets the minimum criteria for the accepted report (Figure 4). The minimum criteria for an accepted report are (1) mini research reports suitable to predetermined templates; and (2) the similarity index of miniresearch reports is $\leq 30 \%$.

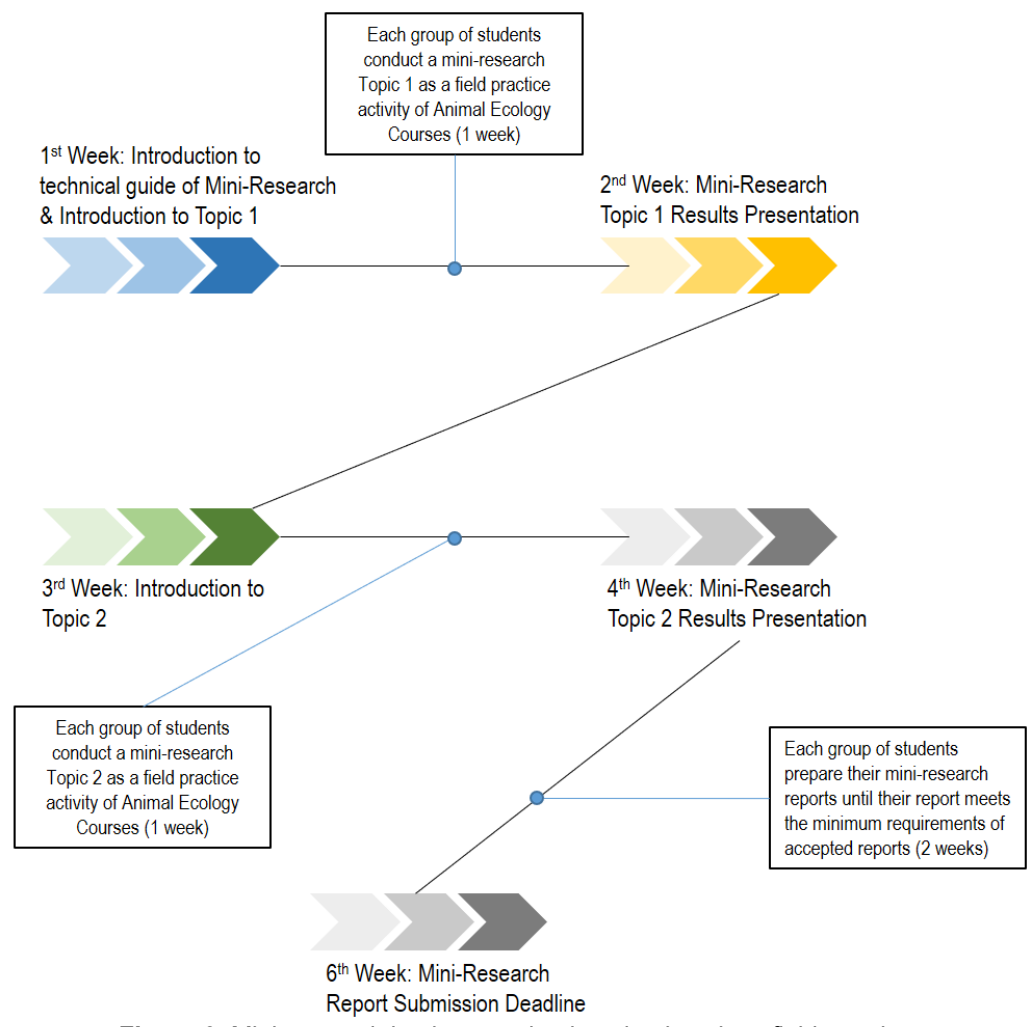

Figure 3. Mini-research implementation in animal ecology field practice 


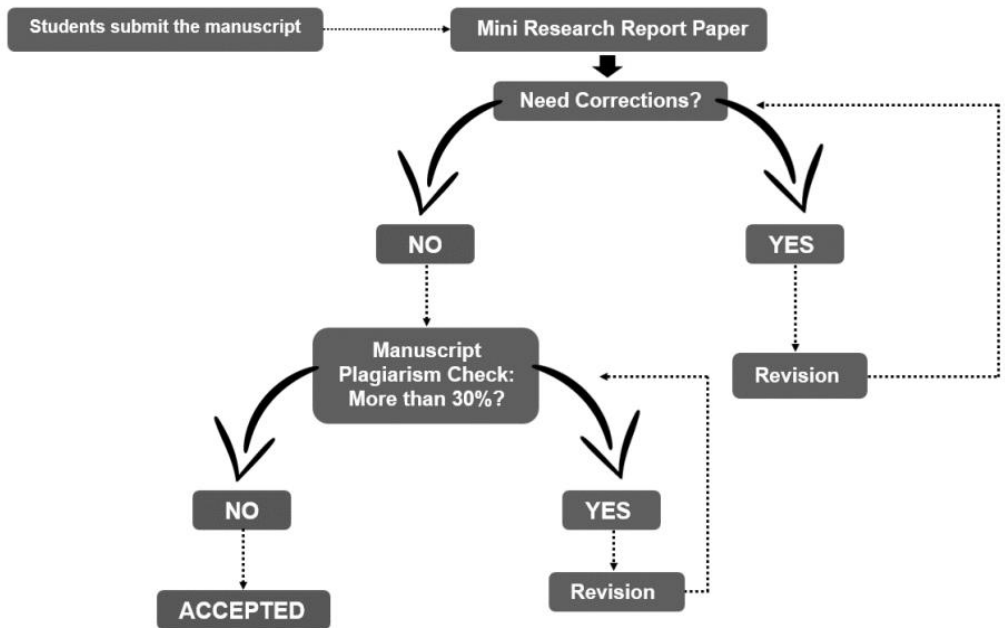

Figure 4. The flowchart of mini-research reports submission

In the collect \& analyze evidence phase, the data were collected during the implementation process of miniresearch including scientific writing skills and communication skills. Scientific writing skills were assessed through the assessment of mini-research reports made by students. Communication skills were assessed during the mini-research results presentation session. The scoring rubric for mini-research report assessment was designed to assess the mini-research report as objectively as possible and to evaluate each part of the report independently. The scoring rubric used in this study to assess mini-research report is presented in the Table 1.

Table 1. Scoring rubric for mini-research report assessment

\begin{tabular}{|c|c|c|c|c|c|c|}
\hline \multirow{2}{*}{ No. } & \multirow{2}{*}{ Rubric } & \multicolumn{5}{|c|}{ Possible Score } \\
\hline & & A & B & C & D & $E$ \\
\hline \multicolumn{7}{|c|}{ Plagiarism (10pts) } \\
\hline 1 & $\begin{array}{l}\text { The similarity index of Mini-Research reports is } \leq 30 \% \\
\leq 30 \%(2.5), \leq 20 \%(5.0), \leq 15 \%(7.5), \leq 10 \%(10)\end{array}$ & 10 & 7.5 & 5.0 & 2.5 & 0 \\
\hline \multicolumn{7}{|c|}{ Report Session (80pts) } \\
\hline \multirow[t]{4}{*}{2} & Title (10pts) & & & & & \\
\hline & Title is Descriptive & 4 & 3 & 2 & 1 & 0 \\
\hline & English Title & 4 & 3 & 2 & 1 & 0 \\
\hline & Names of group members & 2 & 1.5 & 1.0 & 0.5 & 0 \\
\hline \multirow[t]{2}{*}{3} & Abstract (10pts) & & & & & \\
\hline & Informative (brief summary of the report) & 10 & 7.5 & 5.0 & 2.5 & 0 \\
\hline \multirow[t]{3}{*}{4} & Introduction (10pts) & & & & & \\
\hline & Background Information (with relevant outside source) & 8 & 6 & 4 & 2 & 0 \\
\hline & Include research aims & 2 & 1.5 & 1.0 & 0.5 & 0 \\
\hline \multirow[t]{5}{*}{5} & Methods (10pts) & & & & & \\
\hline & Brief description of the research methodology & 4 & 3 & 2 & 1 & 0 \\
\hline & Study Sites (include map) and Sampling Technique & 2 & 1.5 & 1.0 & 0.5 & 0 \\
\hline & Research Procedure (sampling procedure) & 2 & 1.5 & 1.0 & 0.5 & 0 \\
\hline & Data Analysis & 2 & 1.5 & 1.0 & 0.5 & 0 \\
\hline \multirow[t]{4}{*}{6} & Results (10pts) & & & & & \\
\hline & Description of the results & 4 & 3 & 2 & 1 & 0 \\
\hline & Figure pointed out in the text & 4 & 3 & 2 & 1 & 0 \\
\hline & Correct format of Figure and Table & 2 & 1.5 & 1.0 & 0.5 & 0 \\
\hline \multirow[t]{3}{*}{7} & Discussion (10pts) & & & & & \\
\hline & Interpretation of the results & 4 & 3 & 2 & 1 & 0 \\
\hline & Comparison of the data with previously published information & 6 & 4.5 & 3.0 & 1.5 & 0 \\
\hline \multirow[t]{2}{*}{8} & Conclusion (10pts) & & & & & \\
\hline & Contains a brief summary of research results & 10 & 7.5 & 5.0 & 2.5 & 0 \\
\hline \multirow[t]{4}{*}{9} & References (10pts) & & & & & \\
\hline & Correct format of Citation and Bibliography (IEEE style) & 4 & 3 & 2 & 1 & 0 \\
\hline & Relevant Citations & 4 & 3 & 2 & 1 & 0 \\
\hline & Meets the minimum quantity of citation number & 2 & 1.5 & 1.0 & 0.5 & 0 \\
\hline \multicolumn{2}{|c|}{ Total Score } & 90 & & & & \\
\hline
\end{tabular}


Based on the scoring rubric in Table 1, the maximum score of the mini-research report is 90 . The final score is stated on a scale of $0-100$, then the calculation is to divide the student's score by the maximum score then multiply by 100 . The scoring rubric was also designed to assess students' communication skills during the results presentation session as presented in the following Table 2. In the reflect phase, the entire implementation process of mini-research is evaluated.

Table 2. Scoring rubric for verbal communication skills assessment

\begin{tabular}{llc}
\hline No. & Communication Skill(s) & Possible Score \\
\hline 1 & Presentation Media & $0-100$ \\
2 & Oral Presentation & $0-100$ \\
\hline
\end{tabular}

The samples of this research are 52 undergraduate students of the Biology Education Program, University of Palangka Raya. All students sampled are fourth-year students taking animal ecology courses. Samples were divided into six research groups with the aim of facilitating the implementation of mini-research by the students.

The data of this research were analyzed descriptively and quantitatively (descriptive-quantitative). The data on the improvement of scientific writing skills were analyzed quantitatively using the Normalized Gain formula (Hake, 1998).

\section{RESULTS AND DISCUSSION}

The implementation of mini-research is carried out based on the existing implementation procedure in the mini-research technical guide from the middle to the end of the semester for five weeks. During the field practice activities, students work on the mini-research project independently with predetermined topics consisting of two topics related to animal ecology. The implementation of the two topics of the mini-research project was divided into 2 cycles, in the first cycle for topic 1 (earthworm diversity) and the second cycle for topic 2 (insect diversity).

At the first meeting of each cycle, a technical procedure for implementing mini-research was delivered. All details regarding the implementation of mini-research are presented at this stage including a description of the procedure and an explanation of the tools and materials needed by students in carrying out the research. After that students are given the freedom to choose a sampling location for their mini-research project which is first consulted with the field practice supervisor. Students are given 1 week for the implementation of the miniresearch project and preparation for the presentation of the results at the next meeting.

The preparation of the final mini-research report by students was carried out after the presentation of the results of topic 2 in the second cycle. The detailed report submission procedure can be seen in Figure 4. This procedure is made like a procedure for publishing scientific papers in a journal. Student mini-research reports are not just accepted but must pass the review stage by the field practice supervisor. After the report being reviewed is deemed in accordance with the provisions, the report is accepted. The provisions referred to in general are according to the template and have a similarity index of less than or equal to $30 \%$.

Students gain real experience in doing research and report the results in the form of scientific papers through this mini-research project. Students get lessons from the experiences they have had during field practice, this has a positive impact on students. Learning from real experiences or commonly known as experiential learning has a significant effect in gaining knowledge and developing social skills and students' attitudes (Kolb \& Kolb, 2005; Piščalkiené \& Ingemann, 2019; Tanaka et al., 2016; Voukelatou, 2019).

Students' scientific writing skills were assessed by the way they wrote the mini-research report and students' communication skills were assessed by the way they delivered the results during the presentation session using an assessment rubric that had been designed for each of the skills assessed. The results of the assessment of students' scientific writing and communication skills are described in detail as follows.

The results of the assessment of students' scientific writing skills in cycle 1 showed quite good achievement (Table 3), but at some points, it still needs to be improved, especially in plagiarism (38\%) and abstract writing $(67 \%)$. Based on the survey results, students admitted that they knew little about plagiarism and had never even known before. Students obtained a fairly good score on other points with several times corrections to the report. At this stage, students realized that scientific writing requires extra effort and good skills. According to Simmons et al. (2014) good scientific writing is a skill that is acquired personally through years of practice and the crucial challenge as an instructor is teaching our students how to write critically, logically, and concisely, while recognizing the value of compliance with well-established scientific standards. 
In the learning through practice, engagement in authentic environments and activities shapes and facilitates occupational learning. According to Billett (2013) it provides access to an understanding of the situational performance criteria, including the situated practice culture on which occupational performance is centered.

Table 3. Scientific writing skills based on mini-research report assessment results (cycle 1)

\begin{tabular}{|c|c|c|c|c|c|c|c|c|c|c|c|c|c|}
\hline \multirow[b]{3}{*}{ No. } & \multirow[b]{3}{*}{ Group } & \multicolumn{10}{|c|}{ Score } & \multirow[b]{3}{*}{ Total } & \multirow[b]{3}{*}{$\begin{array}{l}\text { Final } \\
\text { Score }\end{array}$} \\
\hline & & \multicolumn{5}{|c|}{ Plagiarism } & \multicolumn{5}{|c|}{ Report Session } & & \\
\hline & & $\%$ & : & $\stackrel{\oplus}{ \pm}$ & 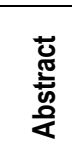 & $\begin{array}{l}\text { 은 } \\
\text { 음 } \\
\text { 인 } \\
\text { 은 }\end{array}$ & $\begin{array}{l}\frac{0}{0} \\
\stackrel{0}{ \pm} \\
\text { to }\end{array}$ & 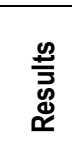 & 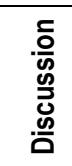 & 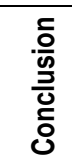 & 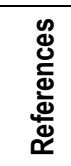 & & \\
\hline 1 & Group 1 & 23 & 2.5 & 9 & 7.5 & 10 & 9 & 8 & 8.5 & 10 & 9 & 73.5 & 81.7 \\
\hline 2 & Group 2 & 17 & 5.0 & 9 & 10 & 10 & 9 & 9 & 8.5 & 10 & 9 & 79.5 & 88.3 \\
\hline 3 & Group 3 & 18 & 5.0 & 10 & 7.5 & 10 & 10 & 8.5 & 7 & 10 & 9.5 & 77.5 & 86.1 \\
\hline 4 & Group 4 & 24 & 2.5 & 9 & 5 & 8 & 6.5 & 8 & 8.5 & 7.5 & 10 & 65.0 & 72.2 \\
\hline 5 & Group 5 & 16 & 5.0 & 10 & 5 & 9 & 6.5 & 9 & 7 & 5 & 9.5 & 66.0 & 73.3 \\
\hline 6 & Group 6 & 27 & 2.5 & 8 & 5 & 7.5 & 6.5 & 6 & 5 & 5 & 6.5 & 52.0 & 57.8 \\
\hline & Total & & & 55 & 40 & 54.5 & 47.5 & 48.5 & 44.5 & 47.5 & 53.5 & & \\
\hline & ercentage & & & $92 \%$ & $67 \%$ & $91 \%$ & $79 \%$ & $81 \%$ & $74 \%$ & $79 \%$ & $89 \%$ & & \\
\hline
\end{tabular}

In the results of the mini-research report corrections submitted back to the students, notes are included that can help students improve the report. The results of the second cycle assessment on the students' scientific writing skills showed a significant increase in all points of assessment (Table 4). Students succeeded in lowering the similarity index in their reports. The percentage of achievement for plagiarism point increased from $38 \%$ to $67 \%$. This shows that students are starting to learn how to cite from related references to support their arguments, not just copying all sentences into their reports.

These results also indicate that students get an increase in the percentage of achievement in abstract writing from $67 \%$ to $88 \%$. Students show that they begin to understand writing an abstract from a research report that contains a brief description of the background, methods, objectives and results.

Table 4. Scientific writing skills based on mini-research report assessment results (cycle 2)

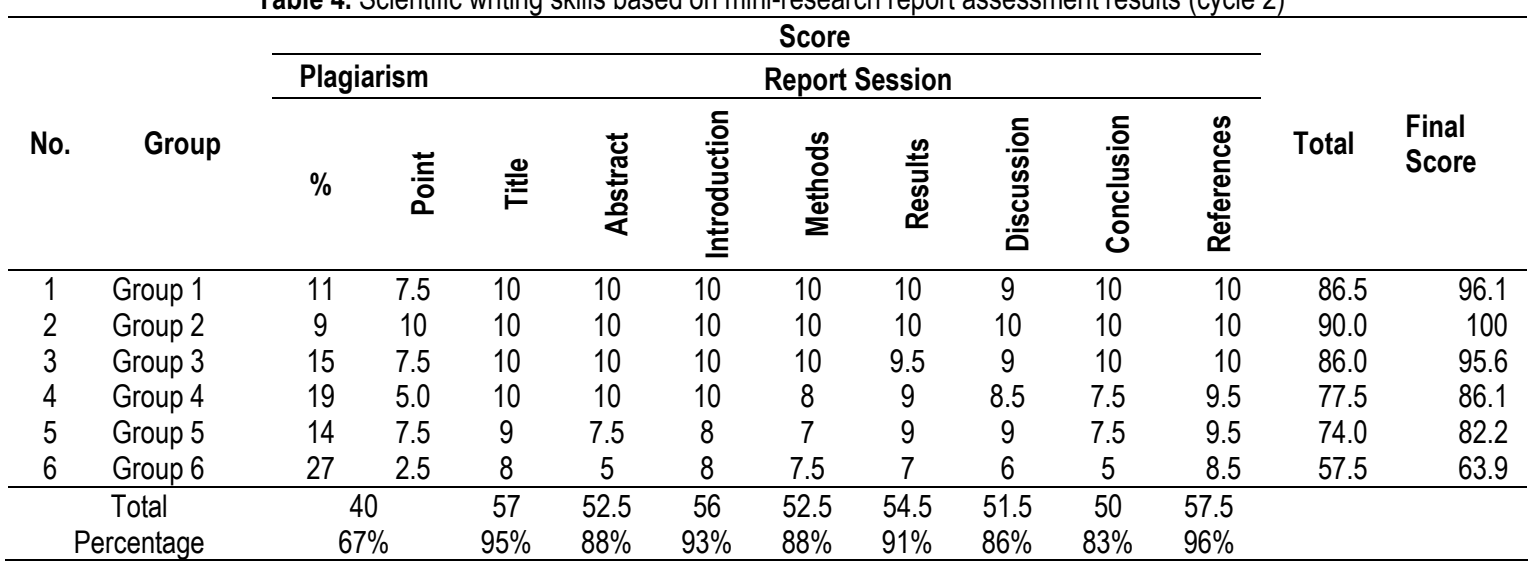

Students get an increase in the percentage of achievement at all assessment points (Figure 5). This means that students can develop their scientific writing skills through this mini-research project including the skills on title formulation, abstract writing, introduction, methods, results, discussion, conclusion, and reference. The results of the normalized gain analysis showed that the overall score for the gain of students' scientific writing skills based on mini-research report assessment was 0.6 in the moderate category (Table 5).

Correction notes that are included on reports that are returned to students can be a means of selfevaluation for students to improve their reports. These corrective notes can also be good evidence for the teacher regarding student learning progress, and therefore what remains to be learned. For the students, these corrections notes are undeniable to the learning process because making errors is considered as a method they use in order to learn (Amara, 2018; Corder, 1967; Metcalfe, 2017; Overbye et al., 2020). This makes students produce better writing along with the learning process (see Figure 6 for an example of miniresearch report), therefore most groups of students in preparing their reports only received one correction in this second cycle (Table 6). 


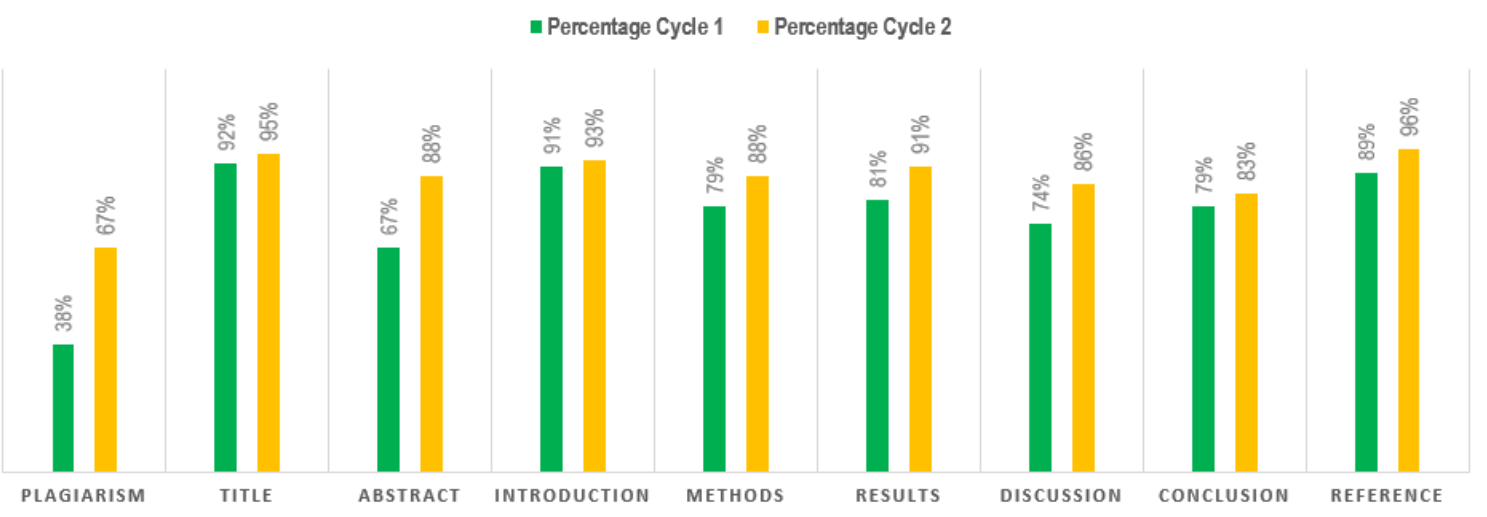

Figure 5. Students' scientific writing skills based on mini-research report assessment: comparison of cycle 1 and cycle 2

Table 5. Students' scientific writing skills improvement category based on the results of normalized gain analysis

\begin{tabular}{cccccc}
\hline \multirow{2}{*}{ No. } & \multirow{2}{*}{ Group } & \multicolumn{2}{c}{ Mini-Research Report Score } & \multirow{2}{*}{ Gain Score (g) } & Gain Category \\
\cline { 2 - 3 } & & Cycle 1 & Cycle 2 & & \\
\hline 1 & Group 1 & 81.7 & 96.1 & 0.8 & High \\
2 & Group 2 & 88.3 & 100 & 1.0 & High \\
3 & Group 3 & 86.1 & 95.6 & 0.7 & High \\
4 & Group 4 & 72.2 & 86.1 & 0.5 & Moderate \\
5 & Group 5 & 73.3 & 82.2 & 0.3 & Moderate \\
6 & Group 6 & 57.8 & 63.9 & 0.1 & Low \\
\hline \multicolumn{7}{r}{} \\
\cline { 2 - 2 }
\end{tabular}

Table 6. Number of revision of each group mini-research report

\begin{tabular}{llcc}
\hline \multirow{2}{*}{ No. } & Group & \multicolumn{3}{c}{ Number of Revision } \\
\cline { 3 - 4 } & Group 1 & Cycle 1 & Cycle 2 \\
\hline 1 & Group 2 & 4 & 1 \\
2 & Group 3 & 2 & 1 \\
3 & Group 4 & 3 & 1 \\
4 & Group 5 & 3 & 2 \\
5 & Group 6 & 4 & 2 \\
6 & & 6 & \\
\hline
\end{tabular}

In this study, students' verbal communication skills in delivering research results were also assessed. The results of the assessment show an increase in the skills of communicating research results in a presentation, both in terms of presentation media and oral presentation. Table 7 shows the details of verbal communication skills assessment results.

Table 7. Students' verbal communication skills

\begin{tabular}{|c|c|c|c|c|c|c|c|}
\hline \multirow[b]{2}{*}{ No. } & \multirow[b]{2}{*}{ Group(s) } & \multicolumn{2}{|c|}{ Cycle 1} & \multirow[b]{2}{*}{ Total } & \multicolumn{2}{|c|}{ Cycle 2} & \multirow[b]{2}{*}{ Total } \\
\hline & & $\begin{array}{l}\text { Presentation } \\
\text { Media }\end{array}$ & $\begin{array}{c}\text { Oral } \\
\text { Presentation }\end{array}$ & & $\begin{array}{c}\text { Presentation } \\
\text { Media }\end{array}$ & $\begin{array}{c}\text { Oral } \\
\text { Presentation }\end{array}$ & \\
\hline 1 & Group 1 & 72 & 70 & 71.0 & 80 & 75 & 77.5 \\
\hline 2 & Group 2 & 80 & 78 & 79.0 & 85 & 78 & 81.5 \\
\hline 3 & Group 3 & 75 & 75 & 75.0 & 80 & 78 & 79.0 \\
\hline 4 & Group 4 & 70 & 70 & 70.0 & 80 & 75 & 77.5 \\
\hline 5 & Group 5 & 70 & 70 & 70.0 & 78 & 75 & 76.5 \\
\hline 6 & Group 6 & 68 & 70 & 69.0 & 75 & 75 & 75.0 \\
\hline & Total & 435 & 433 & & 478 & 456 & \\
\hline & Percentage & $73 \%$ & $72 \%$ & & $80 \%$ & $76 \%$ & \\
\hline
\end{tabular}

All the findings in this study indicate that the implementation of the mini-research project in the field practice of the animal ecology course helps students develop scientific writing and communication skills. In this study, students are conditioned to conduct research and report the results of their research in the form of scientific papers as their mini-research project report. In the report submission process, it is simulated like a standard procedure for publication in a scientific journal with minimum criteria and predetermined templates. 
Therefore, students' scientific writing skills improve through a learning process that provides real experiences for students in writing scientific papers.

Mini-research project implementation in the animal ecology field practice represents project-based learning (PjBL) in general. Project-based learning had a significant effect on the students writing skills and help the student to improve their writing skills in a collaborative environment (Aghayani \& Hajmohammadi, 2019; Hasani et al., 2017; Mandow et al., 2014; Rachmawati \& Asmara, 2018). In addition, project-based learning can also be used as a means to train and improve student communication skills (Awang \& Daud, 2015; Kovalyova et al., 2016; Mandow et al., 2014; Sagala et al., 2019), because in this study students are required to deliver each result of their mini-research project verbally in a scientific presentation.

Students' responses to the implementation of mini-research in animal ecology field practice were collected online using google forms. The survey results showed that the implementation of mini-research received good feedback from students and they suggested that it be implemented in other courses as well. Table 8 shows the students' responses in detail.

Table 8. Students' responses to the mini-research implementation

\begin{tabular}{|c|c|c|}
\hline No. & Question(s) & Response(s) \\
\hline 1 & $\begin{array}{l}\text { Are you satisfied with the Mini-Research Implementation in } \\
\text { Animal Ecology field practice? }\end{array}$ & $\begin{array}{l}60 \% \text { (Very Satisfied) } \\
29 \% \text { (Satisfied) } \\
10 \% \text { (Neutral) } \\
2 \% \text { (Unsatisfied) } \\
\text { Figure } 7\end{array}$ \\
\hline 2 & $\begin{array}{l}\text { Did you acquire new knowledge and skills in scientific writing } \\
\text { through this Mini-Research activity? }\end{array}$ & $\begin{array}{l}98 \% \text { (Yes) } \\
2 \% \text { (No) }\end{array}$ \\
\hline 3 & Regarding question number 2 , how significant is it? & $\begin{array}{l}58 \% \text { (Very Significant) } \\
38 \% \text { (Significant) } \\
4 \% \text { (Neutral) }\end{array}$ \\
\hline 4 & Knowledge/Skills did you acquire? & $\begin{array}{l}\text { Plagiarism } 63.6 \% \\
\text { Abstract } 77.3 \% \\
\text { Introduction } 65.9 \% \\
\text { Methods } 63.6 \% \\
\text { Results (Data Presentation) } 61.4 \% \\
\text { Discussion } 61.4 \% \\
\text { Citation and Reference } 75 \%\end{array}$ \\
\hline 5 & Describe the benefits you get from Mini-Research? & $\begin{array}{l}\text { a. Gain new practical field experience that is } \\
\text { different from previous practices. } \\
\text { b. acquire knowledge about how to write good } \\
\text { scientific papers. } \\
\text { c. know the importance of avoiding plagiarism in } \\
\text { scientific writing. } \\
\text { d. develop scientific writing skills and interpret } \\
\text { research results well. } \\
\text { e. obtain an overview of how to plan and conduct } \\
\text { research, and how to process data and report it in } \\
\text { the form of scientific papers. } \\
\text { f. helps make it easier to understand the concepts } \\
\text { in animal ecology courses. }\end{array}$ \\
\hline 6 & $\begin{array}{l}\text { Describe the obstacles when you did Animal Ecology field } \\
\text { practice activities with Mini-Research? }\end{array}$ & $\begin{array}{l}\text { Outdoor practical field activities are limited due to the } \\
\text { COVID- } 19 \text { pandemic. }\end{array}$ \\
\hline 7 & $\begin{array}{l}\text { Does this Mini-Research need to be implemented in other } \\
\text { courses? }\end{array}$ & $\begin{array}{l}98 \% \text { (Yes) } \\
2 \% \text { (No) }\end{array}$ \\
\hline
\end{tabular}

Table 7 and Figure 7 show that $89 \%$ of students are satisfied (60\% very satisfied; $29 \%$ satisfied) with the implementation of the animal ecology field practice with the mini-research concept. They significantly gained knowledge and skills in scientific writing. 
JPBI (Jurnal Pendidikan Biologi Indonesia)

Vol. 7, No. 2, July 2021, pp. 159-170

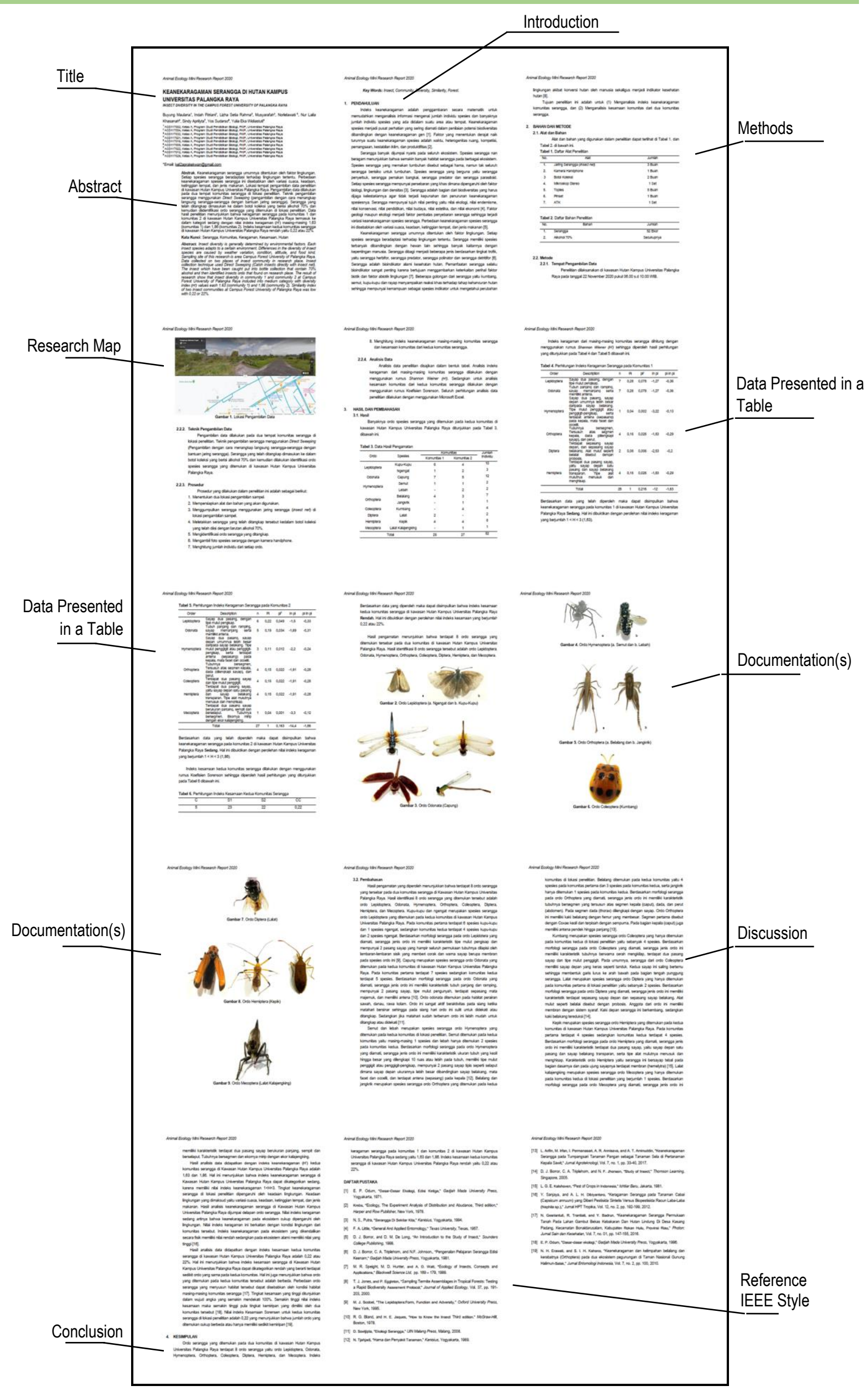

Figure 6. Mini-research report 


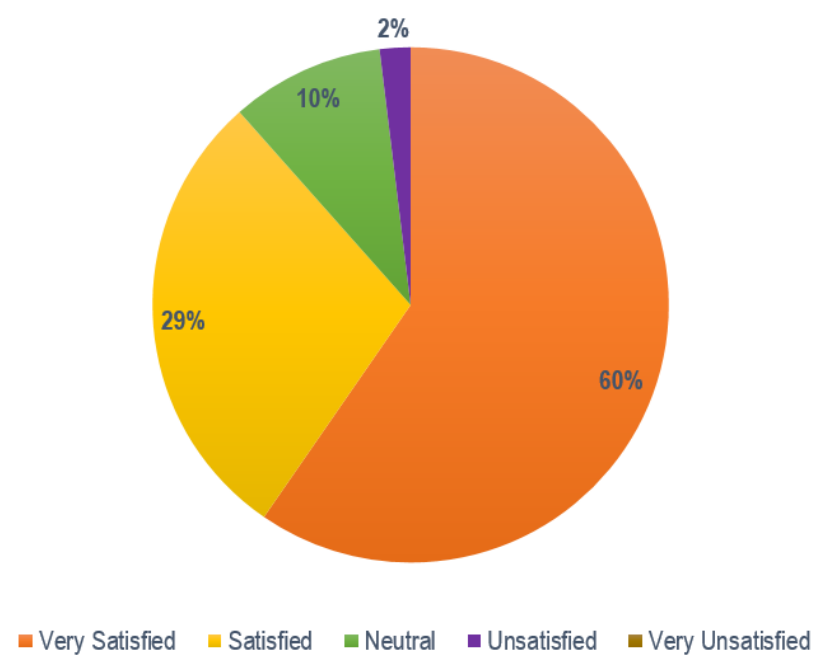

Figure 7. Students' satisfaction of mini-research implementation

Information regarding the benefits and obstacles of implementing mini-research in the field practice of animal ecology from the student's point of view was also obtained from this study. Students gain practical field experience that makes them feel like they are doing research. Through this mini-research they are trained to plan and conduct research and communicate the results independently. Students gained precious knowledge about the importance of avoiding plagiarism in scientific writing and developed skills in scientific writing and research results interpretation. The only obstacle that students experienced was the limited outdoor practical field activities due to the covid-19 pandemic. This obstacle makes the implementation of mini-research less than optimal based on the student's point of view. But overall, they all are satisfied with this kind of learning experience.

\section{CONCLUSION}

This study concludes that the mini-research project is feasible and can be implemented in lectures, especially in a field practice activity, to train students in developing scientific writing and communication skills. The results show that overall score for the gain of students' scientific writing skills based on mini-research report assessment was 0.6 in the moderate category with details as mush as $98 \%$ of the students are gained the knowledge and skill in scientific writing. Students' communication skills also showed better improvement from cycle 1 to cycle 2 which was assessed during the presentation session. The articles of each group of the students are compiled in a mini-research reports of animal ecology field practice as a sign of accomplishment in this learning activity.

\section{REFERENCES}

Aghayani, B., \& Hajmohammadi, E. (2019). Project-based learning: promoting efl learners' writing skills. Journal: A Journal on Language and Language Teaching, 22(1), 78-85. https://doi.org/10.24071/ Ilt.2019.220108

Amara, N. (2018). Correcting students' errors: theory and practice. Current Educational Research, 1(5), 45 57. http://educationalresearch.in/index.php/cer/article/view/24

Awang, H., \& Daud, Z. (2015). Improving a communication skill through the learning approach towards the environment of engineering classroom. Procedia - Social and Behavioral Sciences, 195, 480-486. https://doi.org/10.1016/j.sbspro.2015.06.241

Bangert-Drowns, R. L., Hurley, M. M., \& Wilkinson, B. (2004). The effects of school-based writing-to-learn interventions on academic achievement: a meta-analysis. Review of Educational Research, 74(1), 2958. http://www.jstor.org/stable/3516060

Barroga, E., \& Mitoma, H. (2019). Critical thinking and scientific writing skills of non-anglophone medical students: a model of training course. Journal of Korean Medical Science, 34(3), e18-e18. https:// doi.org/10.3346/jkms.2019.34.e18

Billett, S. (2013). Learning through practice: beyond informal and towards a framework for learning through practice. Revisiting Global Trends in TVET: Reflections on Theory and Practice, 86. https://unevoc. 
unesco.org/fileadmin/up/2013_epub_revisiting_global_trends_in_tvet_chapter4.pdf

Corder, S. P. (1967). The significance of learner's errors. IRAL: International Review of Applied Linguistics in Language Teaching, 5(4), 161-170. https://doi.org/10.1515/iral.1967.5.1-4.161

Graham, S., Harris, K., \& Hébert, M. (2011). It is more than just the message: presentation effects in scoring writing. Focus on Exceptional Children, 44. https://doi.org/10.17161/foec.v44i4.6687

Hake, R. R. (1998). Interactive-engagement versus traditional methods: a six-thousand-student survey of mechanics test data for introductory physics courses. American Journal of Physics, 66(1), 64-74. https://doi.org/10.1119/1.18809

Hasani, A., Hendrayana, A., \& Senjaya, A. (2017). Using project-based learning in writing an educational article: an experience report. Universal Journal of Educational Research, 5(6), 960-964. https:/l doi.org/10.13189/ujer.2017.050608

Javed, M., Juan, W. X., Nazli, S., Princpal, V., Oxford, M., High, C., \& Vehari, S. (2013). A study of students' assessment in writing skills of the english language. International Journal of Instruction, 6(2). http:// www.e-iji.net/dosyalarliji_2013_2_9.pdf

Kolb, A. Y., \& Kolb, D. A. (2005). Learning styles and learning spaces: enhancing experiential learning in higher education. Academy of Management Learning and Education, 4(2), 193-212. https://doi.org/ 10.5465/AMLE.2005.17268566

Kovalyova, Y. Y., Soboleva, A. V., \& Kerimkulov, A. T. (2016). Project based learning in teaching communication skills in english as a foreign language to engineering students. International Journal of Emerging Technologies in Learning, 11(4), 153-156. https://doi.org/10.3991/ijet.v11i04.5416

Mandow, A., Martínez, J. L., \& García-Cerezo, A. (2014). Project-based learning of scientific writing and communication skills for postgraduate students. 2014 IEEE Frontiers in Education Conference (FIE) Proceedings, 1-4. https://doi.org/10.1109/FIE.2014.7044022

Metcalfe, J. (2017). Learning from errors. Annual Review of Psychology, 68(1), 465-489. https://doi.org/ 10.1146/annurev-psych-010416-044022

Moore, R. (1994). Writing as a tool for learning biology. BioScience, 44(9), 613-617. https://doi.org/ $10.2307 / 1312461$

Nilson, L. B. (2003). Teaching at its best (2nd ed.). San Francisco, CA: Anker. https://eric.ed.gov/ ?id=ED480297

Overbye, K., Bøen, R., Huster, R. J., \& Tamnes, C. K. (2020). Learning from mistakes: how does the brain handle errors. Frontiers for Young Minds, 8. https://doi.org/10.3389/frym.2020.00080

Pechenik, J. A. (2013). A short guide to writing about biology (8th ed.). Boston: Pearson. https:// www. pearson.com/us/higher-education/program/Pechenik-Short-Guide-to-Writing-about-Biology-A-8thEdition/PGM3556.html

Permana, F. H., \& Setyawan, D. (2020). Peningkatan kualitas pembelajaran model flipped classroom dalam meningkatkan karakter siswa melalui lesson study. Prosiding Seminar Nasional IKIP Budi Utomo, 223228. https://doi.org/10.33503/prosiding.v1i01.893

Permana, F. H., Sukma, E., \& Wahyono, P. (2021). The use of distance learning through whatsapp and google meeting to identify differences in biology learning outcomes. Biosfer, 14(1), 86-98. https:// doi.org/10.21009/biosferjpb.20094

Piščalkienè, V., \& Ingemann L. H. (2019). Benefits of experiential based learning: a case of students participation in the project "villages on move baltic." Visuomenès Sveikata, 28(6), 5-15. https:/l doi.org/10.5200/sm-hs.2018.064

Rachmawati, D., \& Asmara, C. H. (2018). Reading and writing: development of project-based learning (PBL) approach. International Conference on English Language Teaching (ICONELT 2017), 48-53. https:// www.atlantis-press.com/article/25888980.pdf

Sagala, Y. D. A., Simajuntak, M. P., Bukit, N., \& Motlan, M. (2019). Implementation of project-based learning (PjBL) in collaboration skills and communication skills of students. Proceedings of the 4th Annual International Seminar on Transformative Education and Educational Leadership (AISTEEL 2019), 705709. https://www.atlantis-press.com/article/125928462

Simmons, A. D., Larios-Sanz, M., Amin, S., \& Rosell, R. C. (2014). Using mini-reports to teach scientific writing to biology students. The American Biology Teacher, 76(8), 551-555. https://doi.org/10. 1525/abt.2014.76.8.9

Somekh, B. (2006). Action research: a methodology for change and development. MacGraw-Hill Education, Open University Press. https://eric.ed.gov/?id=ED493196 
Stephenson, N. S., \& Sadler-McKnight, N. P. (2016). Developing critical thinking skills using the Science Writing Heuristic in the chemistry laboratory. Chemistry Education Research and Practice, 17(1), 72-79. https://doi.org/10.1039/C5RP00102A

Tahira, M., \& Haider, G. (2019). The role of critical thinking in academic writing: an investigation of efl students' perceptions and writing experiences. International Online Journal of Primary Education, 8(1), 1-30. https://eric.ed.gov/?id=EJ1243509

Tanaka, K., Dam, H. C., Kobayashi, S., Hashimoto, T., \& Ikeda, M. (2016). Learning how to learn through experiential learning promoting metacognitive skills to improve knowledge co-creation ability. Procedia Computer Science, 99, 146-156. https://doi.org/10.1016/j.procs.2016.09.107

Tonissen, K. F., Lee, S. E., Woods, K. J., \& Osborne, S. A. (2014). Development of scientific writing skills through activities embedded into biochemistry and molecular biology laboratory courses. International Journal of Innovation in Science and Mathematics Education, 22(4), 1-14. https://core.ac.uk/down load/pdf/143897868.pdf

Tripp, D. (2005). Action research: a methodological introduction. Educação e Pesquisa, 31(3), 443-466. https://doi.org/10.1590/S1517-97022005000300009

Voukelatou, G. (2019). The contribution of experiential learning to the development of cognitive and social skills in secondary education: a case study. Education Sciences, 9(2). https://doi.org/10.3390/ educsci9020127 